\title{
versants
}

REVISTA SUIZA DE LITERATURAS ROMÁNICAS

Revista publicada bajo el auspicio del Collegium Romanicum

(Asociación de los Romanistas Suizos)

con el apoyo de la Academia Suiza

de Ciencias Humanas y Sociales

NÚMERO 63:3 (FASCÍCULO ESPAÑOL)

2016

TEORÍA/S

Número editado

por Bénédicte VAUTHIER

SLATKINE

GINEBRA

Difusión en Francia:

HONORÉ CHAMPION ÉDITEUR,

París 

des sciences humaines et sociales www.assh.ch

(C) 2016. Éditions Slatkine, Genève.

www.slatkine.com

Reproduction et traduction, même partielles, interdites.

Tous droits réservés pour tous les pays.

ISBN 978-2-05-102791-5 ISBN 978-2-05-102792-2

ISSN 0256-9645 


\section{Inhibición y destabuización en la productividad cultural de acontecimientos históricos*}

La noción de acontecimiento, repudiada durante décadas por los historiadores, ha retornado al centro del debate desde el comienzo de su rehabilitación en los años 70 y ha vuelto a despertar el interés sobre todo de la filosofía, los estudios de los medios de comunicación y las disciplinas cuyo objeto de investigación es la producción cultural en las diversas formas de expresión artística (el cine, la imagen, la literatura, etc.). Mientras que algunos trabajos se centran en la cuestión de definir qué es un acontecimiento, cómo se relaciona con la narratividad y en qué circunstancias merece llevar los epítetos histórico y grande, otros muchos se han dedicado a analizar los productos culturales (novelas, piezas de teatro, películas, etc.) que tematizan determinados sucesos del pasado, a menudo en relación con la problemática de la memoria, es decir, con una visión esencialmente retrospectiva que valora en particular la adecuación de la representación ficticia a la facticidad de los hechos y somete las obras comentadas a un examen no sólo estético, sino también ético y político.

Sin descartar por completo la aproximación hermenéutica y valorativa, el enfoque centrado en la productividad cultural considera los sucesos históricos como punto de partida, como estímulo inicial que genera la creación de obras, no como objeto central de la investigación ni como piedra de toque real para evaluar la calidad ética y estética de los productos culturales. Es decir, optamos $1^{\circ}$ por privilegiar la ficcionalización y la autonomización en la medida en que los productos culturales se alejan y se independizan del acontecimiento originario y $2^{\circ}$ por indagar en las causas que fomentan o frenan este proceso. Pues desde el momento en que ocurren, los sucesos atraen el interés de los creadores de ficciones al mismo tiempo que imponen límites a su aprovechamiento cultural a causa del respeto que se debe a las víctimas, de las dimensiones de la

\footnotetext{
* Este artículo se redactó en el marco del proyecto de investigación La productivité culturelle (narrative) d'événements historiques: les répercussions culturelles de six événements au Mexique et en Espagne (19682004), del Fonds National Suisse (Proyecto FNS Núm. 100012_146097), que se realizó en la Universidad de Lausana bajo la dirección del profesor Marco Kunz, con la colaboración de Rachel Bornet, Salvador Girbés y Michel Schultheiss.
} 
destrucción, el poder censurador de personas o instituciones implicadas, etc. Cuanto más cerca se encuentra del acontecimiento, más obligación tiene el producto cultural de afirmar y demostrar su seriedad (su compromiso, su solidaridad con las víctimas, su integridad ética y moral, su veracidad, etc.) para protegerse contra la acusación de frivolidad que pesa sobre toda creación cultural. Con la distancia temporal, espacial, cultural e individual, en cambio, se reduce la fuerza inhibitoria (tabuizadora) del acontecimiento y se libera su plena productividad cultural que ahora se puede desarrollar en direcciones antes obstaculizadas, mutiladas o prohibidas por la cercanía del suceso. Esta tensión entre inhibición y destabuización es uno de los factores principales que regulan la productividad cultural de acontecimientos históricos, por lo que propongo aquí algunas reflexiones sobre lo que mueve a los creadores a producir obras a partir de desastres y atrocidades, sobre lo que les impide dar rienda suelta a su imaginación y lo que, al contrario, les hace perder el respeto a los hechos documentados.

\section{Pulsión nerónica vs. complejo adorniano}

Ante la atracción del horror y los tabúes que vedan su libre usufructo, el productor cultural se encuentra en un dilema entre dos fuerzas antagónicas: la pulsión nerónica y el complejo adorniano. Los biógrafos del emperador romano acusaron a Nerón de haber provocado una catástrofe, el incendio de la capital del Imperio, y de haber contemplado desde una torre la destrucción que causaban las llamas sin conmoverse por el sufrimiento de las víctimas; al contrario, fascinado por la belleza del espectáculo, lo usó como escenario en el que cantó, vestido de su disfraz de actor, un poema suyo sobre la conquista de Troya ${ }^{1}$. Más aún, según Dion Casio (Historia romana, 62, 16), lo que motivó al pirómano fue el deseo de observar con sus ojos de artista algo semejante a lo que pudo haber visto Príamo cuando ardía Troya. Llamo pues pulsión nerónica la inclinación a ceder ante la espectacularidad estética del acontecimiento y usarlo como fuente de inspiración para el propio trabajo creativo.

\footnotetext{
1 Cfr. Suetonio, De Vita Casearum, liberVI, Nero, 38.
} 
Es a esta pulsión nerónica que parece haber sucumbido, desde la pasividad del espectador, el compositor alemán Karlheinz Stockhausen cuando provocó un escándalo al calificar los atentados del 11-S en Nueva York como la mayor obra de arte posible ${ }^{2}$. Se trata de un caso raro de un embeleso esteticista incondicional ante la hecatombe, pues normalmente la producción cultural postcatastrófica es contrarrestada y frenada por lo que denomino el complejo adorniano, es decir, los remordimientos de conciencia de quien se siente culpable al aprovechar como materia prima de su creación o como fuente de un placer contemplativo un suceso que causó inmenso dolor y muerte masiva. En un célebre ensayo de 1951 titulado "Kulturkritik und Gesellschaft» (Crítica de la cultura y sociedad), el filósofo Theodor W. Adorno formuló por primera vez su actitud escéptica ante la producción cultural después del holocausto: «nach Auschwitz ein Gedicht zu schreiben ist barbarisch» $»^{3}$ (escribir un poema después de Auschwitz es bárbaro). Matizada, aunque nunca desmentida, en textos posteriores, esta polémica frase de Adorno debe leerse, más que como una prohibición, como una advertencia acerca de la alta responsabilidad ética del creador que se enfrenta a los horrores de nuestro mundo. Sin embargo, el complejo adorniano, con su inherente descalificación de la poesía y otras formas de expresión artística, posee un poder inhibitorio considerable, que sólo lentamente se va debilitando en la medida en que crece la distancia entre el suceso y el acto de producción cultural que se funda en él.

Bien mirado, lo más aberrante del comentario de Stockhausen sobre el 11-S fue la comparación con el lado creativo de la obra de arte al hablar de los terroristas como si hubieran sido músicos que durante mucho tiempo habían ensayado para finalmente inmolarse en un apoteósico

\footnotetext{
${ }^{2}$ En una entrevista, una semana después de los atentados del 11-S, Stockhausen dijo literalmente: «Also - was da geschehen ist, ist natürlich - jetzt müssen Sie alle ihr Gehirn umstellen - das größtmögliche Kunstwerk, was es je gegeben hat, dass also Geister in einem Akt etwas vollbringen, was wir in der Musik nie träumen könnten, dass Leute zehn Jahre üben wie verrückt, total fanatisch für ein Konzert und dann sterben. Das ist das größte Kunstwerk, was es überhaupt gibt für den ganzen Kosmos. Stellen sie sich das doch vor, was da passiert ist, das sind Leute, die sind so konzentriert auf das, auf die eine Aufführung und dann werden 5000 Leute in die Auferstehung gejagt in einem Moment. Das könnte ich nicht. Dagegen sind wir gar nichts als Komponisten [...]» (Schweinfurter Informationsnetz, «Tonbandabschrift Pressekonferenz Karlheinz Stockhausen», http://www.swin.de/kuku/kammchor/stockhausenPK.htm [12-11-2014]).

3 Theodor W. Adorno, «Kulturkritik und Gesellschaft», en Petra Kiedaisch (ed.), Lyrik nach Auschwitz. Adorno und die Dichter, Stuttgart, Philipp Reclam jun., 1995, pp. 27-49, p. 49.
} 
concierto suicida, llevando a la muerte -literalmente dijo 'resurrección' (Auferstehung) - a los 5000 'espectadores' del 'concierto': las connotaciones positivas de la noción de obra de arte, la admiración que generalmente suscita y la fama de genio atribuido al artista nos chocan al ser evocadas en el contexto de un atentado que causó tantos muertos, ya que con el prestigio que ennoblece el arte parecen justificar la masacre en nombre del resultado estético. Sin embargo, si lo miramos desde el lado de la recepción del acontecimiento (y de hecho, Stockhausen habló ante todo como espectador y dejando claro que fue un crimen porque el público no sabía que iba a haber un espectáculo ${ }^{4}$ ), es probable que el compositor haya sentido cierta envidia al ver el impacto que tuvo el 11-S sobre una audiencia multitudinaria, algo que ninguna obra de arte nunca ha sido capaz de lograr: el canto de Nerón no pudo competir con el horror causado por el incendio de Roma y la catástrofe no le ayudó a eternizar su obra poética, y ninguna película, novela u ópera podrán nunca emocionar tanto a los espectadores y grabarse tan profundamente en su memoria y hasta en su subconsciente como las imágenes tantas veces repetidas de las Torres Gemelas que se derrumban y de los hombres desesperados que se lanzan al vacío. "Das könnte ich nicht» ${ }^{5}$, dijo Stockhausen admitiendo su impotencia de mero compositor: «Dagegen sind wir gar nichts als Komponisten ${ }^{6}$.

Sería igualmente hipócrita pretender que la fascinación por estas imágenes no es también una experiencia estética como lo sería negar todo valor de los productos culturales para contribuir al trabajo del duelo (Trauerarbeit) después de catástrofes y otros sucesos terribles. Ahora bien, el efecto principal de la contemplación de las imágenes documentales del 11-S no es en absoluto catártico sino, al contrario, traumatizador, por lo que superar este traumatismo, por un lado, y, por otro, liberar la fascinación de la mala conciencia es una tarea que se propone cumplir la producción cultural que sustituye el suceso real por su ficcionalización, su alegoría y/o su simulacro. La cultura nos permite sublimar el acontecimiento, p. ej. viendo una película o leyendo una

\footnotetext{
${ }^{4}$ En la entrevista citada, Stockhausen dijo: «Das Verbrechen ist es deshalb, das wissen Sie ja, weil die Menschen nicht einverstanden waren, die sind nicht in das 'Konzert' gekommen. Das ist klar. Und es hat auch niemand angekündigt, ihr könntet dabei drauf gehen».

5 Traducción mía: «Yo no podría [hacer/lograr] esto».

${ }^{6}$ Traducción mía: «En comparación con esto, los compositores no somos absolutamente nada».
} 
novela con la tranquilizadora certidumbre de que éstas no costaron la vida a nadie (y quizás olvidando, o relegando a una zona remota de nuestra conciencia, que esta película o novela no existirían sin la muerte de miles de víctimas en los hechos que les sirvieron de modelo y razón de ser).

La reacción de Stockhausen, pese a la aberración de su formulación, revela una verdad que admiten también algunos de los que lo critican explícitamente, como lo hace Martin Seel al reconocer que la visión del derrumbe de las Torres Gemelas fue también un acontecimiento estético, como pasa hoy día con muchos sucesos declarados históricos casi al mismo tiempo que suceden:

Viele der heutigen geschichtlichen und kulturellen Ereignisse sind zugleich ästhetische Ereignisse, einfach deshalb, weil sie durch die Inszenierung und Übermittlung der Medien von vornherein auf eine spezifische Weise öffentlich erscheinen. Darum haben politische und sportliche Großereignisse, wenn sie denn echte Ereignisse sind, also den Rahmen des Erwartbaren nachhaltig sprengen, immer einen ästhetischen Charakter ${ }^{7}$.

Explica Seel que debe tratarse de procesos cuya compleja presencia sensual hace patente el potencial de un presente igualmente complejo: tales acontecimientos estéticos no sólo generan un presente alterado, temporalmente desequilibrado, sino que simultáneamente dan testimonio de él, haciéndolo visible públicamente. El acontecimiento histórico en sí, pese a la indudable calidad estética que posee en cuanto fenómeno perceptible, dista mucho de ser una obra de arte o, en términos menos altisonantes, un producto cultural. Pero si nos llega transmitido en su puesta en escena mediática, lo que normalmente implica una selección de imágenes, una narrativización, una dramaturgia, o sea, una estetización inevitable, ya no reaccionamos a una vivencia directa, sino a un suceso presentado como espectáculo (p. ej. televisivo). Y las imágenes del 11-S,

\footnotetext{
7 Traducción mía: «Muchos de los acontecimientos históricos y culturales de hoy son al mismo tiempo acontecimientos estéticos, por la simple razón que, desde el principio, aparecen públicamente de una manera específica a causa de su puesta en escena y transmisión por los medios de comunicación. Por eso los grandes acontecimientos políticos y deportivos, si realmente se trata de auténticos acontecimientos, es decir, si rompen de un modo sostenible el marco de lo previsible, tienen siempre un carácter estético» (Martin Seel, «Ereignis. Eine kleine Phänomenologie», en Nikolaus Müller-Schöll (ed.), Ereignis. Eine fundamentale Kategorie der Zeiterfahrung. Anspruch und Aporie, Bielefeld, Transcript, 2003, pp. 37-47, p. 43).
} 
observa Seel, no sólo ilustraron el derrumbe de los rascacielos neoyorquinos y, con ellos, de una parte del orden mundial, sino también el ocaso de nuestro orden de imágenes del mundo ${ }^{8}$. Las múltiples perspectivas sobre las Torres Gemelas, la insistente repetición de las mismas tomas, la falta de imágenes de los actantes principales, la ausencia, durante horas, de una trama mínimamente estructurada, todo eso se oponía a la dramaturgia mediática habitual, haciendo manifiestos el descontrol y el desconcierto:

diese Inszenierung bildete unter dem Druck der Situation Formen aus, die die bisherigen kinematographischen und literarischen Erfindungen sprengten. Wer hinsah, konnte sehen, wie die Macht des Wirklichen die Ordnungen ihrer Darstellung und Vorstellung außer Kraft setzte. Der Einbruch des Unerwarteten vollzog sich als ein Bruch mit der erwartbaren medialen Präsentation ${ }^{9}$.

¿No podría ser la producción cultural desencadenada por el 11-S una tentativa de reconstituir ese orden destruido, o buscando nuevas formas de representación de ese acontecimiento que rompió el marco de lo habitual (es decir, de innovar las artes de la ficción para responder de manera adecuada a la insólita provocación del suceso), o, al contrario, tratando de reintegrar lo descomunal en el marco de los esquemas representativos habituales (i.e. de normalizar el acontecimiento estética y narrativamente recurriendo a los procedimientos conocidos, por ejemplo, del cine y la literatura)?

Más aún, la fascinación estética -y la obcecación ética- de Stockhausen ante el 11-S se debe quizás a la intuición de que, como escribió Marcel Proust, «certaines réalités transcendantes émettent autour d'elles des rayons auxquels la foule est sensible» ${ }^{10}$, es decir, que tienen una fuerza de irradiación que llega al gran público con una intensidad de que la obra artística no es capaz, motivo por el que el artista y el intelectual pueden llegar a envidiar «la perception par le peuple de cette 'aura' qui entoure les grands événements et qui peut être visible à des centaines de kilomètres» ${ }^{11}$.Y el aura es precisamente lo que, según Walter Benjamin, la obra de arte perdió

\footnotetext{
${ }^{8}$ Martin Seel, op. cit., p. 44.

9 Traducción mía: «esta puesta en escena creó, bajo la presión de la situación, formas que rompieron con las invenciones cinematográficas y literarias anteriores. Quien lo miró bien pudo ver cómo el poder de lo real invalidó los órdenes de su representación e imaginación. La irrupción de lo inesperado se llevó a cabo como una ruptura con la presentación medial esperable». Ibid.

${ }^{10}$ Marcel Proust, À l'ombre des jeunes filles en fleurs, París, Gallimard, 1994, p. 22.

11 Ibid.
} 
en la época de su reproductibilidad técnica: ésta destruye la unicidad y autenticidad del original, pues al alejar al contemplador del hic et nunc de la obra de arte («das Hier und Jetzt des Kunstwerks») ${ }^{12}$, condición imprescindible para que tenga un aura ${ }^{13}$, la reproducción priva la obra de su existencia única en el lugar donde se encuentra el original («sein einmaliges Dasein an dem Orte, an dem es sich befindet») $)^{14}$, y al acercar la reproducción a la situación del receptor actualiza lo reproducido separándolo de la tradición, lo que significa la emancipación de la obra de arte de su nexo parasitario con una ritualidad ${ }^{15}$, pero al mismo tiempo les quita los fundamentos a su testimonio histórico y a su autoridad ${ }^{16}$.

El gran acontecimiento histórico, a su vez, también está estrechamente ligado al lugar y momento en que se produce, pero no tiene ninguna permanencia física, el original es efimero y sólo deja escombros, ruinas, recuerdos: su aura debe de estar en otro sitio. Podemos ver un cuadro en el museo que lo posee, pero si visitamos el campo de batalla post factum ya no vemos la contienda, sino a lo sumo, si llegamos poco después, algunos cadáveres y los estragos de las bombas o, si la distancia temporal es más grande, algún monumento que conmemora los hechos sangrientos, o nada en absoluto en la mayoría de los casos.Y si excepcionalmente nos toca vivir el acontecimiento en su inmediatez e in situ, es muy poco probable que lo podamos contemplar con la concentración y la quietud que exigiría una obra de arte para desplegar todo su potencial estético y significativo y permitir una catarsis.Vivido en el momento de acaecer, el acontecimiento es un desastre o un frenesí, obliga o invita a la participación en cuerpo y alma, pero la cercanía no ofrece las condiciones para poder mirarlo con la distancia necesaria para percibir su aura como «einmalige Erscheinung einer Ferne, so nah sie sein mag» (la aparición irrepetible de una lejanía, cuan cerca que esté).

\footnotetext{
12 Walter Benjamin, «Das Kunstwerk im Zeitalter seiner technischen Reproduzierbarkeit», en Illuminationen. Ausgewählte Schriften, Frankfurt a. M., Suhrkamp, 1977, pp. 136-169, p. 139.

${ }^{13}$ Benjamin define el aura como «einmalige Erscheinung einer Ferne, so nah sie sein mag» (op. cit., p. 142), y la considera como inseparable de la ubicación concreta, en el espacio y el tiempo, de un original único: «Denn die Aura ist an sein Hier und Jetzt gebunden. Es gibt kein Abbild von ihr» (p. 152).

14 Walter Benjamin, op. cit., p. 139.

15 «[...] die technische Reproduzierbarkeit des Kunstwerks emanzipiert dieses zum ersten Mal von seinem parasitären Dasein am Ritual» (Walter Benjamin, op. cit., p. 144).

16 Walter Benjamin, op. cit., p. 140.
} 
Sin embargo, pese a la irremediable ausencia del acontecimiento pretérito, éste tiene un aura perceptible incluso desde muy lejos, y eso porque el acontecimiento en cuanto fenómeno trascendente se está haciendo y va creciendo en la mediatez y en la mediatización, y su aura no disminuye con la masificación de la recepción, sino todo lo contrario, aumenta en la medida en que la noticia alcanza a cada vez más personas capaces de percibirla. Los medios de comunicación aceleran la difusión e intensifican el impacto, de modo que podríamos decir, parodiando el famoso título del ensayo de Benjamin, que hoy día el acontecimiento se encuentra en la época de la (re)productibilidad mediática de su aura. Pues ésta no se origina en la -ya imposible-contemplación única del suceso original, sino en la repetición masificada de las múltiples imágenes y los relatos proliferantes que lo construyen y también lo ritualizan al insertarlo, por ejemplo, en solemnes ceremonias conmemorativas, en actos colectivos de solidarización empática con víctimas o héroes, o en monumentos erigidos tanto en los mismos lieux de mémoire que fueron los escenarios de los sucesos históricos como en otros sitios dentro del territorio para el que el acontecimiento es relevante. Adhiriéndose al acontecimiento, los productos culturales aspiran a participar del aura de la que ellos están despojados, y al mismo tiempo regresan a su parasitismo respecto a un rito, ya no religioso en el sentido estricto del término, pero sí fundador, legitimador, cohesionador, perpetuador y/o identitario de una colectividad que deriva su autodefinición, entre otros factores, de los hitos históricos de su pasado.

La recepción del acontecimiento y la del producto cultural obedecen a leyes e influencias totalmente diferentes, ya que los dos pertenecen a historias distintas, el primero a la de los sucesos que conforman la sociedad (la política, la economía) y el segundo a la de la creación cultural. El balance valorativo, siempre provisional, de la suma de todos esos encuentros entre un producto cultural y sus receptores es lo que decide tanto sobre la posición de la 'obra' en la historia de la cultura en general y de su género en particular, como sobre su prestigio en la jerarquía (el canon) de los valores culturales. Si, por ejemplo, una novela se convierte en una obra canónica de la literatura, esto no tiene nada que ver con el acontecimiento histórico que tematiza -más aún, la mayoría de las novelas longevas no ficcionalizan sucesos reales o lo hacen sólo de manera ocasional, tangencial, y la mayoría de las novelas que se centran totalmente 
en un suceso histórico son insignificantes en términos de historia literaria y acogida por parte de la crítica-, sino con características intrínsecas al texto y factores del campo cultural en que se desarrolla la recepción.

\section{Tlatelolco, México D.F., 1968: tres ejemplos de destabuización}

Tomemos como ejemplo la literatura escrita sobre la matanza de Tlatelolco del 2 de octubre de 1968 en que el ejército mexicano mató a un indeterminado número (entre unos cuarenta y varios centenares) de manifestantes en la Plaza de las Tres Culturas. Este acontecimiento representa un auténtico hito en la historia nacional de México: un lieu de mémoire casi sacralizado (sobre todo en la oposición de izquierdas), un año mítico (la primavera de Praga, el mayo francés, etc.), y una serie de aspectos todavía desconocidos, de misterios no resueltos. Tlatelolco 68 posee, por consiguiente, un poder inhibitorio longevo que, sin embargo, casi medio siglo después ha perdido gran parte de su fuerza tabuizadora: para las nuevas generaciones representa la memoria de sus padres y abuelos, el México del siglo XXI ya no es dominado de la misma forma por el PRI que en 1968, y los muertos de la matanza quedan eclipsados por las mucho más numerosas víctimas que causan la narcoviolencia actual y su represión por el Estado.

En la primera etapa en que el acontecimiento «Masacre de Tlatelolco 1968» empezó a desplegar su productividad cultural, la censura impedía hablar abiertamente del tema y obligaba a los escritores a formular sus críticas de manera indirecta, oblicua: Carlos Fuentes, por ejemplo, ambienta su pieza teatral Todos los gatos son pardos (1970), en la época de la conquista de México y enfrenta en el escenario a Moctezuma y Hernán Cortés, pero en la escena final los personajes del siglo XVI se convierten en mexicanos del presente -aparece un joven «vestido como estudiante universitario; sube por la rampa; los GRANADEROS y los POLICías disparan contra él; el joven cae muerto a los pies de MOCTEZUMA y CORTÉS $»^{17}$-, para así establecer una larga genealogía de lo ocurrido en 1968. Al mismo tiempo, en vista al futuro el acontecimiento

${ }_{17}$ Carlos Fuentes, Todos los gatos son pardos, México D.F., Siglo XXI, 1978, 8ª ed., p. 187. 
«Masacre de Tlatelolco» funcionaba como experiencia iniciática para una buena parte de la posterior oposición al gobierno del PRI que marcó la lenta transición hacia un México diferente: durante décadas predominaban la literatura de testimonio (v. gr. Elena Poniatowska, La noche de Tlatelolco) y sobre todo las obras de ficción, a menudo escritas por participantes y/o testigos de las manifestaciones del 68, que representaban los hechos con cada vez más libertad, pero lo hacían de una manera seria, respetuosa y hasta patética, con ánimo de conmemorar, elucidar y denunciar, por un lado, y por otro con la intención de destacar la relevancia del acontecimiento como momento fundador de una especie de espíritu generacional.

Al observar la evolución de la productividad cultural a partir del acontecimiento, se puede constatar que paulatinamente se debilitan las barreras protectoras que impiden tratamientos irreverentes $-\mathrm{O}$ que podrían ser comprendidos como tales- y el acontecimiento histórico, antes objeto de relatos realistas, documentales, autobiográficos, etc., se convierte en un motivo ficticio cuyo uso queda cada vez menos obstaculizado por tabúes políticos y/o escrúpulos éticos. Una de las formas más frecuentes de aprovechar el potencial narrativo de un acontecimiento en una ficcionalización libre es lo que podríamos llamar la thrillerización, que usa el suceso, y también el interés existente por todo lo que se relaciona con él, como pretexto y contexto a fin de construir un relato con alto suspense, mucha acción, conspiraciones y traiciones, en que se combaten potencias enemistadas en una lucha por el poder en la que el suceso histórico desempeña la función de impulsor y motor de la trama. Siendo este tipo de thriller un género de la cultura de masas con notable potencial de ser un éxito de venta, tanto en la novela como en el cine, la tentación de thrillerizar un acontecimiento no puede ser contrarrestada infinitamente por prohibiciones tácitas y reparos morales.

La fuerza inhibitoria del 68 mexicano, dada la importancia extraordinaria atribuida al suceso, empezó a flaquear solo décadas después. Aunque ciertas especulaciones sobre responsabilidades silenciadas y ocultaciones intencionadas circulaban desde el principio, la masacre de la Plaza de la Tres Culturas tardó mucho en servir de tema para un thriller. La CIA en Tlatelolco (2007), de Manuel Calleros Pavón, representa un intento, por cierto poco logrado, de especular sobre los intereses secretos de Estados Unidos como causa posible de los hechos acaecidos el 2 de octubre de 
1968. El protagonista de esta novela, Howard Hoffman, un negro estadounidense curtido en diversos conflictos bélicos, es un agente de la CIA (pero también vende informaciones a la KGB) que llega al Distrito Federal con la orden de provocar un enfrentamiento entre los estudiantes y el ejército mexicano para impedir así una temida revolución comunista y evitar que México se convierta en un segundo Vietnam -el acontecimiento se integra pues en el marco geopolítico de la Guerra Fría: el plan de la CIA se denomina, como reminiscencia irónica de acciones semejantes, "Operación Mexican Freedom»-, lo que Hoffman consigue con la ayuda de Robert Sanchez (isic!), un latino californiano de la misma agencia. Mientras que con referencias exactas al espacio y la cronología de los sucesos históricos reales se simula un anclaje en lo factual, el autor afirma en una nota paratextual el carácter totalmente inventado de la trama - «Todas las situaciones de esta novela son imaginarias, y cualquier relación con la verdad debe considerarse accidental. Todo es ficticio, excepto la masacre del 2 de octubre en la Plaza de las Tres Culturas de Tlatelolco, ciudad de México»" ${ }^{18}-$, y de hecho, La CIA en Tlatelolco revela ser un poco hábil producto literario, fabricado mediante la combinación de procedimientos y estereotipos del género 'thriller de agentes' y destinado a un público no primordialmente mexicano, que gracias al distanciamiento temporal (39 años) y espacial (la novela salió en Argentina) pudo permitirse libertades que una mayor cercanía habría dificultado o censurado, aunque sin que la fórmula narrativa tuviera éxito en este caso (el libro fue publicado por una editorial de escasa difusión y no tuvo ninguna resonancia crítica). Por cierto, este fracaso estético y comercial no resulta sorprendente: al contrario, muchas novelas sobre acontecimientos históricos recientes son tentativas de autores noveles de beneficiarse de una receta narrativa de probada eficacia tanto como de la celebridad del suceso, a menudo con poco talento y un mínimo de originalidad. En ellos, deseosos de debutar en la literatura, la pulsión nerónica vence más fácilmente el freno que les impone el complejo adorniano.

La falta de prestigio del medio mismo puede ser un impedimento para tratar de acontecimientos importantes. Así ha sido necesaria la emancipación de la novela gráfica, hoy día salida del ámbito de los mal reputados cómics, para que sea admisible contar con viñetas dibujadas hechos graves,

\footnotetext{
${ }_{18}$ Manuel Calleros Pavón, La CIA en Tlatelolco, Buenos Aires, Deauno, 2007, p. 6.
} 
sangrientos, trágicos, reales. A esto se añade un tratamiento libérrimo del tema de Tlatelolco en Operación Bolivar (1999) de Edgar Clément, pues éste desconecta casi totalmente los sucesos ficticios de su contexto histórico, pero conserva la estructura del núcleo central del acontecimiento y establece interesantes nexos mediante una intertextualidad iconográfica y mediática. A primera vista, Operación Bolivar no tiene nada que ver con el movimiento estudiantil de 68, pues se cuenta la historia de un cazador de ángeles en un México de fantasía en que de los huesos molidos de los ángeles se fabrica la droga más poderosa, con ganancias exorbitantes que seducen al arcángel Miguel a traicionar a los seres celestiales convocándolos a una reunión en la Plaza de las Tres Culturas, donde son masacrados por los tiradores del ejército ${ }^{19}$. Ahora bien, numerosos detalles, aparte del lugar mismo, remiten claramente a la matanza de 1968: p. ej., el disparo de unas bengalas es la señal para el ataque desde helicópteros, las palabras Olimpia y olímpico de los agresores se oponen al eslogán ;Venceremos! de los agredidos, se reproducen titulares de la prensa mexicana (p. ej. «Noche de horror en Tlatelolco», "Acribillaron a dos granaderos», etc.), y reconocemos fragmentos de famosos cuadros contra la violencia política, como $\mathrm{El}$ dos de mayo de Goya y Guernica de Pablo Picasso. De esta manera el episodio no sólo se calca sobre el modelo de la matanza de Tlatelolco, sino que amplía la dimensión significativa de ésta concediéndole un valor representativo los manifestantes angelizados equivalen al pueblo masacrado en otros conflictos, como la sublevación anti-napoleónica madrileña de 1808 y la guerra civil española de 1936-1939- al mismo tiempo que lo actualiza por la asociación con la narcoviolencia, mal pandémico en el México actual que no tenía la misma importancia en los años 60.

Un cuento del joven autor coahuilense Carlos Velázquez, incluido en su libro La Biblia vaquera (2008), ilustra desde su título extravagante la distancia que separa el original (el acontecimiento, o mejor dicho la fórmula básica de su narración) de su enésima versión a principios del siglo XXI: «Reissue del facsímil original de la contraportada de una remasterizada Country Bible» ${ }^{20}$. Se presenta pues como una reedición en forma y/o formato nuevo (reissue) de una reproducción fotomecánica (facsímil)

\footnotetext{
19 Edgar Clément, Operación Bolivar, México D.F., Ediciones del Castor, 1999; el episodio de la matanza de ángeles se encuentra en las páginas 110-119.

${ }^{20}$ Carlos Velázquez, «Reissue del facsímil original de la contraportada de una remasterizada Country Bible», en La Biblia vaquera, México D.F., Sexto Piso, 2011, pp.39-46.
} 
paradójicamente original (nótese que no es la originalidad del texto reproducido, sino de la primera reproducción) del paratexto editorial impreso en el reverso (contraportada, o sea, un texto secundario y no autógrafo) de una obra remasterizada, es decir, que ha sido sometida a un proceso técnico digital para mejorar la calidad a partir de una versión anterior, llamada Country Bible, traducción al inglés de la Biblia vaquera, que a su vez constituye una mezcla del Libro vaquero con la Escritura Sagrada, la Biblia, que equivale al relato original del acontecimiento, mientras que el resto del título se refiere a las múltiples etapas por las que aquél ha tenido que pasar para convertirse en el cuento de Carlos Velázquez, a través de un proceso de traducción, hibridación, comentario, inversión y reproducción con medios diferentes.

El acontecimiento en que se inspira sobre todo la parte B del cuento, titulada «Sunny Side Up», es la matanza de Tlatelolco, suceso que constituía un hito histórico en la vida de toda una generación (si no de varias generaciones) de escritores, artistas e intelectuales mexicanos, con una impronta muy fuerte en la cultura del país, pero del que un escritor nacido en el norte diez años después se siente ya muy lejano: el México post-68, con sus nostalgias, reivindicaciones y rencores, ya no es el México norteño posmoderno de Velázquez, su generación ya no se ve como un eslabón en la genealogía tlatelolca. Objeto de ritos de conmemoración, con su lugar de la memoria (y su monumento) en la Plaza de las Tres Culturas, la masacre de Tlatelolco no ocupa para Velázquez una posición central, sino periférica en su visión del país -su centro no es el D.F., sino el norte, o sea, la zona que desde la capital es vista como periferia- y la comprensión de su historia: la reescritura irreverente del suceso marca este alejamiento cometiendo el sacrilegio de la profanación.

De la historia original -esa especie de «Biblia» política de la generación del 68- se mantiene en el cuento el cronotopo Tlatelolco-1968 y la estructura básica, el relato nuclear: después de una serie de marchas de protesta, se produce un enfrentamiento de los manifestantes con el ejército que termina en una masacre. Ahora bien, todos estos elementos se ven alterados y contaminados por el presente y las referencias culturales contemporáneas del autor. Así, p. ej., se dice explícitamente que estamos, por un lado, en el sexenio del gobierno de Díaz Ordaz (1964-1970), poco antes de los Juegos Olímpicos de 1968, se mencionan Tlatelolco y la Plaza de las Tres Culturas, como también la fecha de la matanza, el 2 de octubre, 
y se habla de la participación de un Batallón Olimpia, datos que permiten la identificación inequívoca del suceso histórico. Pero, por otro lado, la protagonista es una joven despachadora de pollos fritos en una cadena de fast food, que en su tiempo libre se dedica a quemar CDs pirateados de cantantes como Alejandra Guzmán (^1968) o Paulina Rubio (^1971) que empezaron sus carreras mucho después del 68, y además existen ordenadores de tipo PC y teléfonos móviles. Mediante el anacronismo sistemático, Carlos Velázquez fusiona la cultura y tecnología de su propia época con el pasado en que ocurrió la masacre de Tlatelolco, cuyo relato representa la transgresión principal, pues se invierte la relación entre víctimas y victimarios. Los que se enfrentan a los soldados en este cuento no son estudiantes, sino los vendedores del mercado negro de Tepito, un barrio bravo del centro de Ciudad de México, que vencen a los granaderos mal preparados para defenderse:

Su [de los soldados] armamento eran pistolitas de agua en comparación con las de sus oponentes. Después de la masacre se desató una carnicería sin descanso en contra de los sobrevivientes, quienes huían y se ocultaban en los departamentos de Tlatelolco y circunvalaciones. Fue inútil, los comerciantes buscaron hasta debajo del último boleto de metro y centenares fueron capturados, algunos recibieron torturas y otros más desaparecieron ${ }^{21}$.

Del gobierno con mano de hierro hemos pasado a la ingobernabilidad de un país cuyas capas populares no respetan a las autoridades y les oponen una resistencia violenta cada vez que intentan aplicar la Ley. Aunque ambientada en 1968, la masacre se produce bajo las condiciones del sexenio de Felipe Calderón (2006-2012), cuando fue redactado el texto: el crimen organizado dispone de mejor armamento que las fuerzas de seguridad y comete las violaciones de los derechos humanos (secuestros, torturas, desapariciones) que en otras épocas habían sido monopolio del Estado, provocando la indignación de la sociedad por razones diametralmente opuestas a las que motivaron las acusaciones contra el Gobierno en el 68: «La sociedad estaba ofendidísima: cómo era posible que el presidente mandara a los soldados, sin preparación, sin armamento, a combatir con los cabrones de los comerciantes tepiteños» ${ }^{22}$. En su reescritura del

${ }^{21}$ Carlos Velázquez, op. cit., p. 43.

22 Carlos Velázquez, op. cit., p. 44. 
acontecimiento, Velázquez victimiza jocosamente a los victimarios de Tlatelolco, pero no con una intención revisionista respecto al pasado, pues mediante la anacronización del cronotopo original no sólo el 68 se contagia del siglo XXI, sino también se reinscribe la violencia del pasado en el contexto del presente. El cuento no es un comentario ni un análisis del 68 histórico, sino más bien una actualización -o una remasterizaciónlúdico-paródica del relato nuclear tlatelolco, y al mismo tiempo una demostración de la longevidad de la productividad cultural que sigue conservando este acontecimiento incluso para una generación que se siente ya tan ajena a él, pero que continúa, con estéticas y funciones nuevas, la larga cadena de representaciones y transformaciones a que alude el título y que se describe en el cuento mismo:

Aquello fue el infierno de una herida que precedió a los Juegos Olímpicos de 1968 y permanece abierta en la memoria del país hasta el presente. En las décadas subsiguientes la matanza inspiraría innumerables canciones, novelas, movimientos, películas, etc. Erigirían monumentos, estatuas, monolitos, plazas, paseos, en honor de los caídos ${ }^{23}$.

El relato de Carlos Velázquez también se inserta en esta misma serie de productos culturales y a la vez la ironiza quitándole al acontecimiento el pathos y el monumentalismo. La distancia temporal, espacial y cultural entre éste y el autor se ha hecho tan grande que es necesario recurrir al anacronismo, la irreverencia, la transgresión del tabú, para acercar el suceso al presente del escritor y así hacer posible un nuevo avatar, la enésima concreción del relato nuclear, con otras palabras: un «reissue del facsímil original de la contraportada de un remasterizado Tlatelolco 1968».

\section{Conclusión}

Alejado de su contexto original, el acontecimiento se va convirtiendo en pretexto: de suceso histórico se transforma en un motivo cultural, de constituir el centro supuestamente factual del interés pasa a ser un escenario en el que se representan peripecias ficticias. Por consiguiente, la relación entre el producto cultural y la Historia va perdiendo relevancia

${ }^{23}$ Carlos Velázquez, op. cit., p. 43. 
$y$, en cambio, crece la importancia de los vínculos que mantiene el producto cultural con géneros y tendencias estéticas. La fuerza inhibitoria va disminuyendo al ritmo de la destabuización creciente, lo que no repercute tanto en la cantidad como más bien en la índole de los productos culturales que el suceso histórico inspira, aunque no es raro observar cierto tiempo de veda entre el acontecimiento y la plena eclosión de su productividad cultural. Este proceso corresponde, de manera simplificada, a una evolución en tres periodos (que, por supuesto, se solapan): $1^{\circ}$ el predominio de la literatura de testimonio, el filme documental y otras formas de la no ficción y los tratamientos culturales sumamente serios en una primera fase, que inicia inmediatamente después del suceso; $2^{\circ}$ la proliferación de ficciones narrativas esencialmente realistas en una segunda etapa, pocos años después, con un afán de atenerse a la «verdad» histórica de los hechos y de elucidar sus zonas todavía oscuras -en estas dos primeras fases, la inhibición ética ejerce un fuerte control sobre lo estético e impone estrechos límites de permisividad-, y $3^{\circ}$, una vez superado el impacto traumático, la liberación destabuizada en la era de las generaciones postraumáticas (o incluso olvidadizas) que coincide generalmente con una reducción de la frecuencia del tema histórico (éste pierde su lugar central, privilegiado y protegido en la memoria colectiva y pasa a formar parte de un repertorio de sucesos disponibles casi ad libitum para ficcionalizaciones de todo tipo) y su progresiva transformación de un factum en mero motivo cultural (p. ej. como trasfondo histórico para contextualizar la trama). La fase de la inhibición fuerte es más o menos larga según el carácter trágico del suceso, el número de víctimas, la importancia que se le atribuye en un contexto nacional y/o internacional, etc., pero aunque puede durar muchas décadas, la debilitación del tabú es a largo plazo inevitable y el grado de tolerancia para las transgresiones va aumentando progresivamente, hasta alcanzar finalmente la destabuización total y definitiva.

Marco KunZ

Université de Lausanne 